\title{
The Golden [Statuette] Age: How Miramax Sold Shakespeare to the Academy
}

\author{
SARAH MARTINDALE, University of Nottingham
}

\begin{abstract}
This article revisits the 71st Academy Award Ceremony in 1999 when Shakespeare in Love picked up seven Oscars from thirteen nominations, controversially beating Saving Private Ryan to be named Best Picture. It is rare for a romantic comedy to win this coveted award, but then this is not just a film about love; it is a film about Shakespeare in love. In its depiction of cultural heritage Shakespeare in Love foregrounds 'the very business of show', remaking the playwright and his theatre in the image of millennial Hollywood. By reducing the distance between the two, the film makes claims to cultural quality worthy of recognition and reward. Shakespeare in Love reflected and capitalised on taste culture of the time and cemented Miramax's reputation as a purveyor of 'Oscar-bait'. This article looks closely at a production context of which this film represents an epitome.
\end{abstract}

Peter Biskind has christened the period between Disney's purchase of Miramax in 1993 and Shakespeare in Love's Best Picture Oscar as a 'Golden Age', in which the company profited from the benefits of being a studio subsidiary while still enjoying the kudos they had cultivated as an indie. Thanks to the financial weight lent by their parent studio, Miramax was able to market and distribute the film widely - it played on nearly two thousand screens in America at the peak of its theatrical run, during Oscar season - and to forcefully promote it among the ranks of the Academy voters. Complementing the authoritative cultural pedigree of the film's subject matter was Miramax's own reputation for 'quality filmmaking', which the film simultaneously drew upon and sought to perpetuate. In this way Shakespeare in Love offered mainstream studio production and romantic comedy content, while also projecting an aura of superior substance thanks to the connotations of the names Shakespeare and Miramax. Cultural hybridity is at the root of the film's Oscar-winning success.

\section{KEYWORDS}

Miramax; Shakespeare; Academy Awards; Oscar; cultural hydridity. 


\section{Introduction}

On Sunday $21^{\text {st }}$ March 1999, following a controversial promotional campaign, the film Shakespeare in Love (Madden 1998) won seven Academy Awards from thirteen nominations. The evening is perhaps best remembered for Gwyneth Paltrow's pink Ralph Lauren dress and her endlessly effusive acceptance speech when she won the Best Actress Oscar for her performance in the film. After the obligatory acknowledgements of the Academy and fellow nominees, the first person Paltrow thanked was Harvey Weinstein, head of Miramax, the film company that he co-founded with his brother Bob. Harvey Weinstein accepted the film's Best Picture Oscar with his fellow producers, and received their additional applause along with the audience's. This was not only the climax of the ceremony; it also cemented Miramax's reputation for championing films to Academy Award nominations and wins. Success in this regard has transferred with Harvey and Bob to The Weinstein Company, with Best Picture Oscars for The King's Speech (Hooper 2010) and The Artist (Hazanavicius 2011). ${ }^{\text {i }}$ Alongside critical acclaim, Shakespeare in Love was a Box Office success. The film was produced relatively inexpensively for $\$ 24$ million (Biskind 2005, 330) and grossed just over $\$ 100$ million at the American Box Office and a further $\$ 50$ million from the rest of the world (Biskind 2005, 361). Ultimately the film earned nearly $\$ 280$ million and was ranked the ninth most profitable film of 1998 (Shone 2004, 277). This article considers what factors may have recommended to Shakespeare in Love to Academy voters and the cinema-going public alike.

It is rare for a romantic comedy to win the Best Picture Oscar, but then the title of this victorious film suggests one factor that propelled it so far beyond the usual status accorded to its genre. It is not just a film about love; it is a film about Shakespeare in love. While the revered playwright brings gravitas to the film, Shakespeare in Love employs postmodern playfulness in order to blur established cultural boundaries. It is saturated with clever historical jokes, often involving real figures from Early Modern London, and witty references to Shakespeare's works. ${ }^{\text {ii }}$ At the same time there are also allusions made to Hollywood cinema, with equivalence drawn between the historical and contemporary creative contexts. The film's depiction of the relationships between artists, investors and consumers makes clear that it is self-consciously concerned with 'the very business of show' (as the character Makepeace puts it). This is an attractive feature of the film because it connects the Shakespearean past with contemporary filmmaking, suggesting that inspired/inspiring culture is not bygone and inaccessible, the exclusive preserve of intellectuals who are trained to appreciate it, but is available today in cinemas.

There is a strong feeling of connection between past and present established by the anachronistic details that pepper the film and draw parallels between Shakespearean theatre and Hollywood filmmaking. Features such as the car chase transposed to Thames wherry boats; the unwelcome interjections of the boatmen in accordance with cab driver stereotypes; the unemployed actor working as a waiter and reeling off the daily specials; and the diverse mass audience of engrossed punters who watch Romeo and Juliet; all cultivate an impression of cultural continuity from then to now. The implications of this past/present parallel seem just as significant and intriguing as the film's appropriation of Shakespeare. Shakespeare in Love addresses cinematic, as well as literary and dramatic, modes and thereby ensures that it offers something for everyone. King (2009) uses Shakespeare in Love and Miramax as a case study in his examination of changing filmmaking practices in Hollywood, marked by films that cultivate the impression of alterity and superiority to the norm. This article is interested in the 'scale of different levels of potential engagement' (98) that King identifies; and 
specifically considers how the film mobilises Shakespeare as an allegory for 'Indiewood', courting industry acclaim by valorising the system in which it was produced.

\section{Recasting Shakespeare as Will}

Scholars have identified Shakespeare in Love as 'an exemplum of the film industry's concerted attempt to wrest Shakespeare back from the academy in the name of "the people" (Mayo 2003, 299). This argument rests primarily on the film's depiction of the playwright as a genius producing timeless works of universal relevance, a myth of authorship that has been superseded in Shakespeare criticism (Burt 2000, 215). By giving access to the playwright's (fanciful and romanticised) process of creation, the film 'reduces the distance between viewer and text' (Davis \& Womack 2004, 155). Rather than engage with the complexities and uncertainties of Shakespeare's material and cultural history, the film constructs a culturally normative persona (Iyengar 2001) with wide appeal (Klett 2001, 37). Shakespeare in Love is not only a film about Shakespeare's theatre and his play Romeo and Juliet; it is also a lavish recreation of Elizabethan England, a glossy romantic comedy, a postmodern appropriation of cultural heritage, and an Oscar-winning product. In this way, the film displays what Pidduck (2001) refers to as 'a canny mix of sensibilities' (132).

The film's hybrid cultural status was a feature of the public discourse that accompanied its release. According to Forrest's (1999) assessment in the Observer newspaper, it 'makes dumb people feel smart, and smart people feel like they're slumming it'. These two cultural perspectives are a feature the coverage in Total Film magazine. In the article (Pearce 1999) devoted to Shakespeare in Love, the film's director, John Madden, praises the quality of the script, meaning that the ultimate success of the film becomes associated with its literary provenance. Alongside the article an explanatory section provides background information about 'all those deceased arty people', for those who might not already be aware of their cultural significance. The magazine's review (Cochrane 1999) a few pages later reassures the readers that the film 'works on many levels', describing it as 'an entertaining history lesson' that has 'the ability to appeal to more than Shakespeare buffs'.

Scholars and journalists rightly point out that the film blurs established cultural boundaries, presenting Shakespeare as simultaneously ancient and modern, authoritative and accessible, literary/theatrical and cinematic, mysterious and familiar. Rather than concentrate on intellectually contested elements of its protagonist's life and work, this film presents the man and his plays as approachable, even enticing. It achieves this within the generic framework of quality costume drama, simultaneously conveying historical import and contemporary relevance, cultural heritage and cinematic appeal, intellectual consequence and entertainment value. This article offers an analysis of the production context in which this cultural hybridity was created.

\section{Miramax and the 'Quality' Aura}

The impression that Shakespeare in Love is a universal cinematic product that will engage people at all levels of the cultural hierarchy is not just the upshot of its filmic characteristics. It is also a consequence of the carefully constructed image of its production company, Miramax, which was at the forefront of developments in the American film industry during the 1990s. At the end of the first performance of Romeo and Juliet within Shakespeare in Love, the diegetic audience are shown to be first awestruck and then ecstatic. This art is transcendent, the film implies, it will affect everyone, even the most culturally suspicious, as represented by the puritanical preacher Makepeace, who is moved to tears by the play. By 
portraying audience response in this way, the film is seeking to make claims about its own nature, encouraging the cinemagoer to react in a similar fashion. Thus Shakespeare in Love reinforces a perception that has been central to Miramax's commercial success, the idea that the company prizes artistic value above all other considerations.

In his book Down and Dirty Pictures (2005) Biskind recounts the story that Harvey Weinstein, co-founder of Miramax, tells to explain his motivation as a movie executive: as a teenager he went to see Truffaut's The 400 Blows (1959) thinking it was a porn film, and the experience, he claims, changed his life and established his love of cinema (15). According to Biskind (2005), this tale is an integral element of the 'Miramax mythology, the origins legend' (406), which seeks to represent the company as a small family business - set up and run (until 2005) by the Weinstein brothers, and named after their parents, Miriam and Max that champions controversial or marginal films because of a belief in their cultural importance. During the 1980s and early 1990s, Perren $(2001 ; 2012)$ explains that the modus operandi of Miramax was to buy independent and foreign films, which they promoted using exploitation marketing techniques that utilised sex or controversy, in the hope that they would 'crossover' from the art house circuit to wider distribution. ${ }^{\text {iii }}$ This approach proved highly successful with films like sex, lies, and videotape (Soderbergh 1989) and Reservoir Dogs (Tarantino 1992). As such, French (2006) points out, 'Miramax represents the most evident example of a Hollywood studio facilitating corporate growth by adopting the hybrid notion of a venerable and irreverent product' (136).

These corporate practices made an impact; so much so that Disney bought the company in 1993. In this way Miramax became something of an industry template. Other major studios sought to purchase small distributors or establish their own subsidiary divisions in order to capitalise on this type of low-budget, high-profit enterprise, while the existing independent (or indie) sector began to emulate Miramax's aggressive marketing strategies (Biskind 2005, 193). King (2009) terms this production context, in which Miramax played such a significant role, Indiewood. He argues that, as the industrial practices of the major studios intermingled with the creative practices of smaller producers, films were produced that incorporate alternative elements within mainstream forms. Biskind (2005) has christened the period between Disney's purchase and Shakespeare in Love's Best Picture Oscar as Miramax's 'Golden Age', in which the company profited from the financial benefits of being a studio subsidiary, and began producing 'feel-good movies', while still enjoying the 'enormous critical goodwill' they had cultivated as an independent distributor (375-6). Because Miramax was so successful in promulgating its image as a promoter of innovative cinematic material, it was not until the Oscar campaign for Shakespeare in Love that the press came to realise that there had been a shift in the company's identity (Perren 2001, 36-7).

In New York magazine, just days before the $71^{\text {st }}$ Academy Awards ceremony, Finke (1999) wrote a column bemoaning the possibility that Miramax's film might beat Saving Private Ryan (Spielberg 1998) to the Best Picture award. She dismissed the former as 'two hours of Elizabethan fluff', while describing the latter as 'one of the most gut-wrenching war movies ever made'. Finke's (1999) argument was that Miramax were waging a dirty campaign, deploying 'over-the-line' promotional tactics and 'studio-level spending'. It does, superficially at least, seem astonishing, given Stephen Spielberg's status in Hollywood and the weighty subject matter and mould-breaking approach of his film, that it was beaten to the Oscar by a light-hearted historical romance. However, Shakespeare's cultural status was one of a number of factors in the film's success. 
Thanks to the financial weight lent by their parent studio, Miramax was able to produce a prepossessing vision of Elizabethan London, with beautiful costumes and spectacular sets. Having done this, they then had the money to market and distribute the film widely - it played on nearly two thousand screens in America at the peak of its theatrical run, during Oscar season $^{\text {iv }}$ - and to forcefully promote it within the ranks of the Academy voters. At the same time the film benefited from an authoritative cultural pedigree that insulated it against charges of being just another piece of escapist, romantic nonsense. There is, as King (2009) points out, a careful thematic balance struck in the film overall between art as 'meaningful' and as 'enjoyable', with 'the commercial interests in the theatre stressing the importance of sources of popular attraction, against or alongside the more serious or tragic dimensions of the creative work' (104). Biskind (2005) provides an account of the post-production anxiety at Miramax about the ending of the film. According to the company's executive Vice President of production and development, Jack Lechner, 'The test screenings allowed us to focus in on what was holding the audience back. And we fixed it' (quoted in Biskind 2005, 330). While the film does not provide the happy resolution conventional to a romantic comedy, the inspiration Shakespeare receives from his muse Viola for Twelfth Night serves to mitigate the tragedy of the fact that the lovers cannot be together, and offers them both the possibility of a new beginning through the deathless medium of art.

Placing Shakespeare in the title and at the heart of the film allowed it to demand serious critical attention, and the presence of intellectual jokes (like the characterisation of John Webster as a macabre teenager, which plays on the bloody nature of his tragedies) ensured that commentators could not dismiss it out of hand. Complementing the Bardic gravitas was Miramax's own reputation as an indie film brand (Perren 2012, 177-8), which the film simultaneously drew upon and sought to perpetuate. In this way Shakespeare in Love offered glossy studio production and dependable romantic comedy content, while also projecting an aura of superior cultural substance thanks to the connotations of the names Shakespeare and Miramax.

\section{The Combination of History and Hollywood}

While for many scholars the character of Will represents an embodiment of the romantic mythology that surrounds the figure of Shakespeare, I would argue that he can equally be identified as a substitute for the film's screenwriter. In Shakespeare in Love the play that will eventually become Romeo and Juliet is initially envisaged as 'a pirate comedy'. This is, of course, an overtly comic detail given that the finished piece is a renowned tragedy of starcrossed love, but the choice of humorous genre also has an implicit resonance. The involvement of playwright Sir Tom Stoppard with the film is well-known, but what is frequently overlooked is that his role was in developing an existing script by the American Marc Norman. As a screenwriter Norman's most high profile work prior to Shakespeare in Love was the critically derided Box Office disaster Cutthroat Island (Harlin 1995), a swashbuckling pirate caper. By having Will work on Romeo and Ethel the Pirate's Daughter before the intervention of fate, Norman establishes a link between himself and Shakespeare, despite their temporal and cultural differences. Even without knowing this, however, it is possible to discern within Shakespeare in Love an intention to celebrate the writer's struggle for recognition and reward: by implying that even the most respected of authors was human and fallible, the film suggests that anyone is capable, with the right inspiration, of creating great art. 
By making Shakespeare the victim of dismissive treatment - described at one point as 'Nobody. The author' - the film suggests that contemporary screenwriters, whose work is as yet unheralded, might potentially be as talented as the Bard. The iniquitous system within which Will struggles to express himself and achieve recognition is surely intended to correspond to the modern Hollywood in which Norman toils. Various elements of the film can function as characterisations of Miramax's corporate practices: one former employee is quoted, for example, as saying that working for the company 'was like having your feet held to the fire' (Biskind 2005, 70). The opening sequence of Shakespeare in Love depicts this experience as the Elizabethan financier Hugh Fennyman uses it as a torture method in an attempt to extract monies owed from the theatre impresario Philip Henslowe. This illustrates the idea of commercial interests dominating creativity in artistic endeavour. Similarly there is a knowing reference to business ruses in the following exchange, as the two characters calculate how investment can be recouped from a new production:

HENSLOWE: But I have to pay the actors and the author.

FENNYMAN: A share of the profits.

HENSLOWE: There's never any ...

FENNYMAN: Of course not!

HENSLOWE: (impressed) Mr Fennyman, I think you may have hit on something.

It is claimed that Miramax's commercial achievements in the 1990s stemmed from its ability to drive down the costs of filmmaking, applying the techniques of the small-scale independent sector to more expensive projects and reaping considerable economic rewards (Biskind 2005, 258). One way in which the company accomplished this was by keeping actors' salaries low, their films becoming characterised 'by well-known actors working for scale because of their belief in the script's explosive subject matter' (Perren 2001, 37). Gwyneth Paltrow, for example, took a pay cut of half-a-million dollars from her previous rate for Shakespeare in Love (Biskind 2005, 329). When Miramax films did prove commercial and lucrative the company was allegedly not keen to share the profits, even with those who had a supposed stake in the product. Despite the fact that it was his brainchild, the remarkable success of Shakespeare in Love did not provide Marc Norman with any extra financial benefits and his feelings about the situation are on record: 'All I know is, a picture that makes $\$ 300$ million worldwide does not provide money for people with net points. I'm going to put that on my tombstone' (Biskind 2005, 371-2). This avoidance of transparency on the part of production companies is worked into the Elizabethan context:

HENSLOWE: Ned Alleyn and the Admiral's Men are out on tour. I need actors. Those here who are unknown will have a chance to be known.

ACTOR: What about the money, Mr. Henslowe?

HENSLOWE: It won't cost you a penny! Auditions in half-an-hour!

This exchange points to the evasiveness of an industry that can leave its practitioners feeling fiscally hard done by. ${ }^{v}$ Another joke about Hollywood hierarchies is built into the handbill advertising the first performance of Romeo and Juliet in the film, which reads: 'By 
permission of Mr Burbage, a Hugh Fennyman production, of Mr Henslowe's presentation, of the Admiral's Men in performance, of the excellent and lamentable tragedy, of Romeo and Juliet, with Mr. Fennyman as the Apothecary'. Endless production credits are, of course, a common feature of modern Hollywood films, which often require a huge amount of development and investment. In light of this the details on the play's poster can be seen as another comic incursion of current practices into the historical context, as can Henslowe's misapprehension that Marlowe was killed in a quarrel over the billing rather than the bill. Indeed, allusions to modern filmmaking in Shakespeare in Love can be used to reflect on the circumstances surrounding the film's production and Best Picture Oscar triumph.

In the film the preposterous credits prefacing Romeo and Juliet are due to the fact that adversity has been overcome by creative cooperation, with one company of actors allowing another to use their theatre. This portrayal of an ideal production environment of professional camaraderie is at odds with the story that Biskind (2005) tells about the production of the film itself. In what was apparently an abnormal move, Harvey Weinstein took a producer credit for Shakespeare in Love because of his personal attachment to the project, and this is claimed as a bone-of-contention between him and another of the producers, Ed Zwick, who had been removed from the directorial role by Miramax despite spending years developing the film (Biskind 2005, 327-30). Having failed to persuade Norman and Zwick, the originators of Shakespeare in Love, to remove their producer credits from the film, Biskind (2005) contends that Harvey barged Zwick out of the way at the Academy Awards Ceremony, preventing him from making an acceptance speech when the film won the Best Picture Oscar (370).

Taking this view, Harvey Weinstein's behaviour corresponds to that of Fennyman, whose name is the most prominent feature of the promotional material for Romeo and Juliet, while Shakespeare, the writer, is not even mentioned. There are other similarities that can be drawn between the fictional and real-life producers. During the course of the film Fennyman develops from a violent, demanding bully into what the published screenplay describes as a 'born-again theatre groupie' (Norman and Stoppard, 87), who is determined to make his mark on a creative level. The Weinstein brothers' aggressive business approach is the stuff of Hollywood legend (Biskind 2005, 69-74), yet there is a sentimental streak too, as manifest in Harvey's proclamation in 2000 that 'the company would henceforth make only films with happy endings' (Biskind 2005, 397). Accompanying this romanticism is a tendency to be controlling, which has earned him the sobriquet 'Harvey Scissorhands' in reference to the editorial pressure he exerts on even the most respected of directors (Biskind 2005, 90). Although, as an outsider to the production process, it is not possible to be sure how intentional, personal, accurate or explicit these film/life parallels are, the image of the movie mogul as tough but passionate in business dealings is certainly not one that Harvey Weinstein has sought to avoid.

The only person in Shakespeare in Love to whom Fennyman is deferential is Ned Alleyn, the celebrated star of the Elizabethan stage. It is apparently a similar case with Harvey Weinstein who, Biskind (2005) says, is eager always to present a benevolent face to the famous individuals he does business with (260). Miramax staff have voiced their resentment, claiming that the company 'were just throwing money out the window, $\$ 100,0000$ for Gwyneth Paltrow to have a weekend in Paris just for the hell of it' (Biskind 2005, 338). This lavish treatment allowed Miramax to cultivate what has been described as a 'stable of talent' (Perren 2001, 38), including Shakespeare in Love's leading lady Paltrow, on which it frequently drew. The actor Ben Affleck is also a member of this Miramax family and was, according to Biskind (2005), persuaded by Harvey to take the cameo role of Ned Alleyn in 
the film, despite his significantly higher level of fame than the leading man Joseph Fiennes (329-30). In this way the character of the egomaniacal actor manoeuvred into a supporting position became another instance of life imitating art in relation to Shakespeare in Love.

The key point to note here is that this film is just as knowing about its own cultural context as it is about Shakespearean heritage. Although a full appreciation of the extent of the correspondence between the narrative and its production history requires knowledge of and interest in the workings of the Hollywood industry, the film's depiction of the relationships between artists, investors and consumers makes clear that it is self-consciously concerned with 'the very business of show' (as the character Makepeace puts it). This is an attractive feature of the film because it connects the Shakespearean past with contemporary filmmaking, suggesting that inspired/inspiring culture is not bygone and inaccessible, the exclusive preserve of intellectuals who are trained to appreciate it, but is available today in cinemas.

\section{Star Appeal}

On a textual level, then, it is important to recognise that Shakespeare in Love is sophisticated both as an appropriation of Shakespearean authority and as a Hollywood allegory. Yet the film is not just seeking to engage those who possess the cultural knowledge required to appreciate the literary or the cinematic connotations. It has already been noted that the film's historical aesthetic is appealing, but there are also other sources of attraction. The star meanings brought by the cast are a significant draw of any Hollywood film. This proved a particularly interesting factor in the development of Shakespeare in Love. Pearce reports in the Total Film feature that the screenplay was originally owned by Universal, but the project was scrapped when Julia Roberts withdrew from the lead female role because Daniel DayLewis turned down the role of Will. When Miramax purchased the project from the studio for an exorbitant $\$ 4.5$ million down payment, it was stipulated that the new owners could not 'put a big star in the movie' (Biskind, 328-9). The actors Miramax chose contribute as intertextual cultural reference points to the film's hybridity.

In the late 1990s Gwyneth Paltrow was, in Harvey Weinstein's words, 'the First Lady of Miramax', and Biskind (2005) feels that she served as 'a star he could parade in front of the public to burnish his own reputation' (277). A clue as to the reasons for this symbiotic relationship is provided by Geraghty (2003), who reflects on the impact of genre and nationality on the performances of actresses in the 1990s and concludes that Paltrow is 'a crossover star, with Hollywood glamour and British class' (115). We have already noted that it was just such a combination of old-world and new-world values that Miramax sought to deploy in their corporate iconography. It would seem that this policy extended as far as the company's casting practices. While Paltrow's starring role in the film did not seem out of place because of her 'ability to "pass" in British drama' (Pidduck 2001, 133), her Hollywood profile 'was needed to sell the film in America and overseas' (Pearce 1999, 69). Higson (2003) points out the "idea of "America" appears in Shakespeare in Love in order to ensure that it is 'tailored for American audiences' (143), with the heroine Viola washed up on the Virginian shore as the credits roll. ${ }^{\text {vi }}$ It seems that Paltrow's star meaning serves much the same purpose as this textual feature, broadening the film's horizons beyond the confines of English cultural heritage.

It is reported by Biskind (2005) that Harvey Weinstein initially wanted Ben Affleck to take the part of Will rather than Ned in Shakespeare in Love (329). This would have been a canny 
move that sought to exploit the fact that the actor was in a relationship with Paltrow at the time. Although they did not play the lovers, the couple did share screen space in the film and this in itself may have been a tantalising prospect for those interested in their celebrity. Joseph Fiennes, the actor who did ultimately take the titular role in the film, was not well known prior to 1998. He is, however, the younger brother of Ralph Fiennes, a respected actor who had been Oscar-nominated for his leading role in The English Patient (Minghella 1996), a previous critical and commercial success for Miramax.

The supporting cast of Shakespeare in Love contribute star meanings that complement the film's combination of quality and accessibility. Judi Dench is widely revered for a lengthy acting career that encompasses notable performances on stage, television and film. The high regard in which she is held was demonstrated when her small role (in terms of screen time) as Queen Elizabeth I in Shakespeare in Love won the Best Supporting Actress Oscar. Anthony Sher (Dr Moth) is another respected thespian involved in the film, and he also starred alongside Dench in Mrs Brown (1997), an earlier Miramax costume drama directed by John Madden and lauded by critics. Geoffrey Rush (Philip Henslowe) likewise conferred cultural credibility because he had risen to international fame two years earlier in the musical biopic Shine (Hicks 1996), which earned him a Best Actor Oscar. A number of the other actors had credentials from previous appearances in Shakespearean films or quality costume dramas. ${ }^{\text {vii }}$ In addition, though, the cast members of Shakespeare in Love also have popular culture associations. Dench's authority as the Queen is enhanced, for example, by awareness of her role as $\mathrm{M}$ in the James Bond franchise. There is also a strong association with contemporary comedy established by the film's stars. ${ }^{\text {viii }}$

In this way the eclectic ensemble-cast adds to the 'something for everyone' ethos of Shakespeare in Love. It also enabled the promotion of the film to be customised for particular national contexts: 'In the US, where in 1999 her celebrity was highest, Paltrow was focused upon in the marketing campaign and the run-up to the Oscars, whereas in the UK a wider range of actors including those familiar from British television were employed' (French 2006, 142). It is this widely accessible amalgamation of authenticity and irreverence, heritage and Hollywood, tragedy and comedy, film/TV stars and esteemed actors, which seems to be at the root of the popularity of Madden's film. Due to its cultural hybridity Shakespeare in Love was an innovative, and therefore noteworthy and Oscar-worthy, cinematic product.

\section{Conclusion}

Shakespeare in Love - although not a conventional adaptation or a conventional recipient of the Academy Award for Best Picture - claims and portrays Shakespeare not just as culturally important but also as available to all, with the power to inspire and move anyone at anytime. Scholars are wary of this representation because they view it as perpetuating a hegemonic construction of the Shakespeare canon as consisting of immaculate texts by a romantic, heterosexual genius. In a sense, of course, this is exactly what the film does, presenting a very attractive but fanciful impression of Romeo and Juliet as having a deeply personal significance that is untouched by the passage of time and other cultural influences. However, the film does more than contribute to intellectual debates about Shakespeare and his work; it brings them within the context of Hollywood cinema and, in doing so, it engages in a cultural exchange that, in the hands of Miramax, audiences and the Academy were unable to resist.

\section{References}


Biskind, Peter. Down and Dirty Pictures: Miramax, Sundance, and the Rise of Independent Film. New York: Simon \& Schuster Paperbacks, 2005.

Blakeley, John. 'Shakespearean Relocations: The Final Scene of John Madden's Shakespeare in Love.' Shakespeare Bulletin 27.2 (2009): 249-259.

Burt, Richard. 'Shakespeare in Love and the End of the Shakespearean: Academic and Mass Culture Constructions of Literary Authorship.' Shakespeare, Film, Fin de Siècle. Eds. Mark Thorton Burnett and Ramona Wray. Basingstoke: Macmillan, 2000. 203-231.

Cochrane, Emma. 'Review: Shakespeare in Love.' Total Film 25 (Feb. 1999): 88.

Davis, Todd F., and Kenneth Womack. 'Reading (and Writing) the Ethics of Authorship: Shakespeare in Love as Postmodern Metanarrative.' Literature/ Film Quarterly 32.2 (2004): 153-162.

Finke, Nikki, 'Much Ado About Oscar.' New York Magazine 15 Mar. 1999.

Forrest, Emma. 'To be a hit or not to be...' Observer 24 Jan. 1999: Screen Page, 1.

French, Emma. Selling Shakespeare to Hollywood: The Marketing of Filmed Shakespeare Adaptations from 1989 into the New Millennium. Hatfield: University of Hertfordshire Press, 2006.

Geraghty, Christine. 'Performing as a Lady and a Dame: Reflections on Acting and Genre.' Contemporary Hollywood Stardom. Eds. Thomas Austin and Martin Barker. London: Arnold, 2003. 105-117.

Higson, Andrew. English Heritage, English Cinema. Oxford: Oxford University Press, 2003.

lyengar, Sujata. 'Shakespeare in Heterolove.' Literature/Film Quarterly 29.2 (2001): 122-127.

King, Geoff. Indiewood, USA: Where Hollywood Meets Independent Cinema. London; New York: I.B. Tauris \& Co Ltd, 2009.

Klett, Elizabeth. 'Shakespeare in Love and the End(s) of History.' Retrovisions: Reinventing the Past in Film and Fiction. Eds. Deborah Cartmell, I. Q. Hunter and Imelda Whelehan. London; Sterling, Virginia: Pluto Press, 2001. 25-40.

Mayo, Sarah. "A Shakespeare for the People?" Negotiating the Popular in Shakespeare in Love and Michael Hoffman's A Midsummer Night's Dream.' Textual Practice 17.2 (2003): 295-315.

Norman, Mark and Tom Stoppard. Shakespeare in Love. London: Faber and Faber, 1999.

Pearce, Garth. 'Will, Quills and Bellyaches.' Total Film 26 (Mar. 1999): 67-70. 
Perren, Alisa. 'Sex, Lies and Marketing: Miramax and the Quality Indie Blockbuster.' Film Quarterly 55.2 (2001): 30-39.

Perren, Alisa. Indie, Inc.: Miramax and the Transformation of Hollywood in the 1990s. Austin, TX: University of Texas, 2012.

Pidduck, Julianne. 'Elizabeth and Shakespeare in Love: Screening the Elizabethans.' Film/Literature/Heritage: A Sight and Sound Reader. Ed. Ginette Vincendeau. London: BFI, 2001. 130-135.

\section{Shone, Tom. Blockbuster: How Hollywood Learned to Stop Worrying and Love the Summer. London: Simon \& Schuster, 2004.}

\footnotetext{
${ }^{\mathrm{i}}$ It was reported at the end of 2013 that Miramax, which is no longer owned by Disney, has re-established a connection with the Weinstein brothers in a long-term deal that will include the development of a sequel to Shakespeare in Love (http://www.huffingtonpost.com/2013/12/16/shakespeare-in-love-sequel_n_4453717.html accessed on 23/04/14).

${ }^{\text {ii }}$ Klett (2001) provides a lengthy and informative, though not exhaustive (Blakeley 2009), note at the end of her chapter that extrapolates Shakespearean allusions that can be found within the screenplay.

iii This approach of 'working both ends' of a film is so integral to Miramax's ethos that King (2009) chose to use it as the title of his chapter devoted to the company. As will be shown below, there were promotional opportunities to package Shakespeare in Love as a prestigious and literate film as well as one that features more generic cinematic elements of comedy, romance, spectacle and star appeal.

iv http://www.imdb.com/title/tt0138097/business accessed on 12/09/05.

${ }^{v}$ It is not just Miramax who have had their accounting methods disputed by disgruntled parties. Another example is provided by Biskind (2005) when he describes the animosity that grew up between Merchant/Ivory and Cinecom over the financial management of $A$ Room with a View (96-7).

${ }^{\mathrm{vi}}$ Ancillary information suggests that there was a plan at one time for the outline of modern Manhattan to gradually emerge above the trees over the course of the long shot following Viola's progress up the beach (Blakeley 2009), which would have made the cultural appropriation visually explicit.

vii Simon Callow (Tilney) was in A Room with a View (Ivory 1985) and Maurice (Ivory 1987); Jim Carter (Ralph Bashford) was in Richard III (Loncraine 1995); Rupert Everett (Christopher Marlowe) was in The Madness of King George (Hytner 1994); Colin Firth (Lord Wessex) was in Pride and Prejudice (Langton 1995); Imelda Staunton (the Nurse) was in Twelfth Night (Nunn 1996) and Much Ado About Nothing (Branagh 1993).

viii Everett had recently appeared in the Hollywood rom-com My Best Friend's Wedding (Hogan 1997), while Callow was in the huge British hit Four Weddings and a Funeral (Newell 1994). Tom Wilkinson (Hugh Fennyman) was riding high on the runaway success of stripping comedy The Full Monty (Cattaneo 1997). Martin Clunes (Richard Burbage) and Mark Williams (Wabash) were already well-known from BBC television comedies, Men Behaving Badly (1992-1999) and The Fast Show (1994-2001) respectively.
}

\section{Biography}

Dr Sarah Martindale: Since completing her doctoral research about the status of 'Shakespeare' as a cultural phenomenon, Sarah has worked as a Research Fellow at the University of Nottingham's interdisciplinary hub, Horizon Digital Economy Research, examining the impact of technology innovations on media production and consumption. She is Researcher/Co-Investigator of a project, funded by Research Councils UK, called Charting the Digital Lifespan (EP/L00383X/1). Sarah's research qualitatively explores the ways people attach meaning and value to cultural artefacts and digital interactions.

Email: sarah.martindale@nottingham.ac.uk 